\title{
Antioxidant, Antiinflammatory and Antiinvasive Activities of Biopolyphenolics
}

\author{
Shashwat Malhotra, ${ }^{\text {a, b }}$ Gaurav Shakya, ${ }^{\text {a, b }}$ Ajit Kumar, ${ }^{\text {c d }}$ Barbara W. Vanhoecke, ${ }^{\text {e Ashok }}$ \\ L. Cholli, ${ }^{\text {b }}$ Hanumantharao G. Raj, ${ }^{c}$ Luciano Saso, ${ }^{d}$ Balaram Ghosh, ${ }^{f}$ Marc E. Bracke, \\ Ashok K. Prasad, ${ }^{\mathrm{a}}$ Shyam Biswal, ${ }^{\mathrm{g}}$ and Virinder S. Parmar*a \\ ${ }^{a}$ Bioorganic Laboratory, Department of Chemistry, University of Delhi, Delhi, 110 007, India \\ ${ }^{b}$ Centre for Advanced Materials, University of Massachusetts, One Univeristy Avenue, Lowell, \\ MA 01854, USA \\ ${ }^{c}$ Department of Biochemistry, V.P. Chest Institute, University of Delhi, Delhi, 110 007, India \\ ${ }^{d}$ Department of Pharmacology of Natural Substances and General Physiology, Sapienza \\ University of Rome, Italy \\ ${ }^{e}$ Laboratory of Experimental Cancerology, Department of Radiotherapy and Nuclear Medicine, \\ University Hospital, De Pintelaan 185, B-9000 Gent, Belgium \\ ${ }^{f}$ Institute of Genomics \& Integrative Biology, Mall Road, Delhi, 110 007, India \\ ${ }^{g}$ Department of Environmantal Health Sciences, Johns Hopkins Bloomberg School of Public \\ Health, Baltimore, Maryland 21205, USA \\ E-mail: virparmar@gmail.com
}

\section{Dedicated to Professor Torbjörn Norin}

\begin{abstract}
A large number of polyphenolic and heterocyclic compounds, i.e. 4-methylcoumarins, 4methylthionocoumarins, xanthones, pyrazoles, pyrazolylacrylonitriles, flavones and isoflavones have been tested for their antioxidant activity towards NADPH-catalysed liver-microsomal lipid peroxidation with a view to establish their structure-activity relationship. Inhibition of microsomal lipid peroxidation by 7,8-dihydroxy-4-methylcoumarin (DHMC, 2) and 7,8diacetoxy-4-methylcoumarin (DAMC, 3) was intriguing. We also found that dihydroxy and diacetoxy derivatives of 4-methylthionocoumarin were more potent in comparison to the corresponding coumarin derivatives in inhibiting TNF- $\alpha$ induced expression of ICAM-1. The effect of nine different xanthones has been examined on the modulation of cytokine-induced expression of ICAM-1 in human endothelial cells. 1,4-Dihydroxyxanthone (10) showed enhanced antioxidant activity as well as the inhibition of the expression of cell adhesion molecules, such as ICAM-1, VCAM-1 and E-selectin on endothelial cells in a concentration and time dependent manner. Antioxidant activity of different pyrazoles and pyrazolylacrylonitriles and antiinvasive activity of flavones and isoflavones against solid tumors have also been studied.
\end{abstract}


Keywords: Reactive oxygen species, coumarins, xanthones, flavones and isoflavones

\section{Introduction}

Free radicals originate from a large variety of normal and pathological metabolic transformations, from host-defense against undesirable invasion (chemical or biological), and from host-response to a disturbance of the tissues integrity (due to trauma, cellular damage, etc.). The balance between formation and elimination of free radicals determines the overall stability of a living body. Free-radical chain reactions in the body are initiated mostly by Reactive Species [RS - molecules, ions, free-radicals; Reactive Oxygen Species (ROS) or Reactive Nitrogen Species (RNS)] possessing oxygen or nitrogen atom with an unpaired electron. If more RS are formed than needed for the normal redox-signaling and self-defense of the host, oxidative stress (OS) occurs leading to an oxidative cellular damage, even to cellular death. Free-radicals induce the cell damage by altering the biological activities of lipids, proteins, DNA and carbohydrates.

A great deal of progress has been made in recent years in relating ageing to oxidation in biological cells. The ROS are basically involved in detoxification of invading organisms and chemicals, but stray ROS also initiate lipid peroxidation in healthy cells. Lipid peroxidation initiated by oxygen radicals eventually results in membrane degradation and cell death ${ }^{1}$ leading to diverse pathologies, such as Alzheimer's disease, atherosclerosis, diabetes, Parkinson's disease, etc. ${ }^{2}$ Thus, reduction of the rate of these life-limiting metabolic processes by use of chemicals has been a subject of current research. ${ }^{3-5}$ The negative effects of the RS may be diminished by limiting their formation (control over metabolic transformations and enzymes producing RS) through radical neutralization processes, for example by (a) recombination of the RS already formed (e.g. "radical scavenging"), and (b) altering the RS effects. Inhibitors of the RS synthesis [NADPH- oxidases, xanthine oxidase (XO) inhibitors, leukocytes' antibodies, etc.] may also be administered.

Antioxidants are the substances, which when present at low concentrations compared to those of an oxidisable substrate, significantly delay or prevent oxidation of that substrate. The key role of antioxidants is to intercept and react with free radicals so that cascade effect of ROS propagation is prevented by readily donating its proton to the ROS. Basically, the antoxidant property of a compound is attributed to its ability of $(a)$ oxygen radical scavenging, $(b)$ inhibiting cellular microsomal P-450-linked mixed function oxidation (MFO) reaction, and (c) suppressing the formation of ROS. Thus, antioxidants are considered as remedies to overcome the lethal action of oxygen free radicals. Polyphenolic compounds have drawn greater attention compared to any other class of natural products for their significant biological functions as antioxidants and anticarcinogens or antimutagens, which have led to their recognition as potential neutraceuticals. Among them, phenolics that include coumarins, xanthones, flavones, etc. have attracted considerable attention. 
A criterion for a good antioxidant is that the compound should contain a highly labile hydrogen atom forming a radical, the radical formed should be stable and is not reactive so that it will not participate in the RS propagation step. Sterically hindered phenolic compounds satisfy most of the above-mentioned requirements. Thus, the anti-oxidant and radical scavenging effects of polyphenols are highly cited. We have investigated the antioxidant, anti-inflammatory and anti-invasive effects of a large number of polyphenolics, and heterocyclic compounds belonging to different classes. A review of our work in these areas is presented here.

\section{Coumarins}

Coumarins (known as 1,2-benzopyrones or o-hydroxycinnamic acid-8-lactones) comprise a very large class of phenolic derivatives found in plants and consist of fused benzene and $\alpha$-pyrone rings. Coumarins have attracted intense interest in recent years because of their diverse pharmacological properties. Among these properties, their antioxidant effects have been extensively examined. The pharmacological and biochemical properties, and therapeutic applications of simple coumarins depend upon their pattern of substitution. 4-Methylcoumarins are implicated to have several beneficial pharmacological effects. ${ }^{6,7}$

We, for the first time, have isolated 8-acetyl-7-hydroxy-6-methoxycoumarin and 8methoxycoumarin $^{8}$ from Fraxinus floribunda leaves, trigoforin (3,4,7-trimethylcoumarin $)^{9}$ from Trigonella foenumgraecum stems, troupin (4-methyl-6-hydroxy-7,8-dimethoxycoumarin) ${ }^{10}$ and trigocoumarin [3-(ethoxycarbonyl)methyl-4-methyl-5,8-dimethoxycoumarin] ${ }^{11}$ from Tamarix troupii and Trigonella foenumgraecum, respectively. The leaves of Tamarix troupii are pharmaceutically important and are used for the treatment of dysentery, chronic diarrhoea and leucoderma. In addition, the seeds of Trigonella foenumgraecum are used for curing colic, dysentery, diabetes and chronic cough ${ }^{12}$.

Unsubstituted coumarins appear to be toxic because of their oxidative decarboxylation, resulting in the formation of $o$-hydroxyphenylacetaldehyde or $o$-hydroxyphenyl acetic acid derivatives which form very stable complexes with heavy metals inside the body. ${ }^{13}$ On the other hand, 4-methylcoumarins are reluctant towards oxidative decarboxylation and hence, are nontoxic. ${ }^{13}$ In the recent years, our laboratory is engaged in studying the chemistry and biological effects of 4-methylcoumarin derivatives $1 .^{14,15}$ We have systematically studied the effect of acetoxy, hydroxy and methoxy substituents in a wide variety of 4-methylcoumarin derivatives on initiation, propagation and chain termination of lipid peroxidation in rat liver microsomes (Figure 1). ${ }^{16}$ 


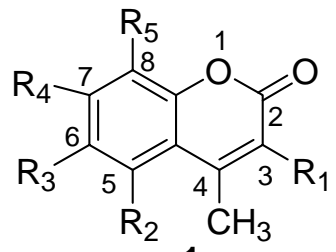

1

$\mathrm{R}_{1}=\mathrm{H} /-\mathrm{CH}_{2} \mathrm{CO}_{2} \mathrm{Et} /-\mathrm{CH}_{2} \mathrm{CH}_{2} \mathrm{CO}_{2} \mathrm{Et} /-\mathrm{Ph} /-\mathrm{C}_{6} \mathrm{H}_{4}-\mathrm{Br} /-\mathrm{C}_{6} \mathrm{H}_{4}-\mathrm{NO}_{2}$

$\mathrm{R}_{2}, \mathrm{R}_{3}, \mathrm{R}_{4}, \mathrm{R}_{5}=\mathrm{H} /-\mathrm{OH} /-\mathrm{OCH}_{3} /-\mathrm{OCOCH}_{3} /-\mathrm{Br}$<smiles>Cc1cc(=O)oc2c(O)c(O)ccc12</smiles><smiles>CCOC(=O)CCc1c(C)c2ccc(OC(C)=O)c(OC(C)=O)c2oc1=O</smiles>

4<smiles>CCOC(=O)CCc1c(C)c2cc(OC(C)=O)c(OC(C)=O)cc2oc1=O</smiles><smiles>CC(=O)Oc1ccc2c(C)cc(=O)oc2c1OC(C)=O</smiles><smiles>CC(=O)Oc1cc2oc(=O)cc(C)c2cc1OC(C)=O</smiles><smiles>[3H]OC1=C(O)C(=O)OC1C(C)O</smiles>

Figure 1. Structures of compounds screened.

The inhibitory effects of monohydroxy- or monoacetoxycoumarins were very marginal, while there was quantum jump in the potency of dihydroxy and diacetoxy derivatives 2-6 to retard the initiation of lipid peroxidation. 4-Methylcoumarins 2-6, having two hydroxy or two acetoxy groups in the benzenoid ring at positions ortho to each other, have shown very strong antioxidant and radical scavenging properties. ${ }^{16}$ These compounds could abolish nearly $90 \%$ of lipid peroxidation. In addition, these dihydroxy- and diacetoxycoumarins were found to possess the ability to terminate the radical chain reaction and propagation of lipid peroxidation along with excellent radical scavenging potency. We have proposed a mechanism of action for their antioxidant effect (Scheme 1). ${ }^{16}$ It is quite clear that such type of resonance stabilized radicals in differently substituted flavonoids are known to confer radical scavenging properties to flavonoids. We believe that there exists the possibility of the conversion of 7,8-diacetoxy-4methylcoumarin (DAMC, 3) to 7,8-dihydroxy-4-methylcoumarin (DHMC, 2) in the presence of the initiating free radical such as peroxy radical or superoxide radical through the formation of reactive ketene (Scheme 1). 
<smiles>CC(=O)Oc1ccc2c(C)cc(=O)oc2c1OC(C)=O</smiles><smiles>CC(=O)Oc1c(O)ccc2c(C)cc(=O)oc12</smiles><smiles>Cc1cc(=O)oc2c(O)c(O)ccc12</smiles><smiles>[R]C=[V]</smiles><smiles>[R]C[CH]</smiles>
$\mathrm{RCH}=\mathrm{CHR}^{\prime}$<smiles>C1CCCCCC1</smiles><smiles>[R]C=CC</smiles><smiles>Cc1cc(=O)oc2c(O)c(O)ccc12</smiles><smiles>CC(O)O</smiles><smiles>[GeH2]O[GeH3]</smiles>

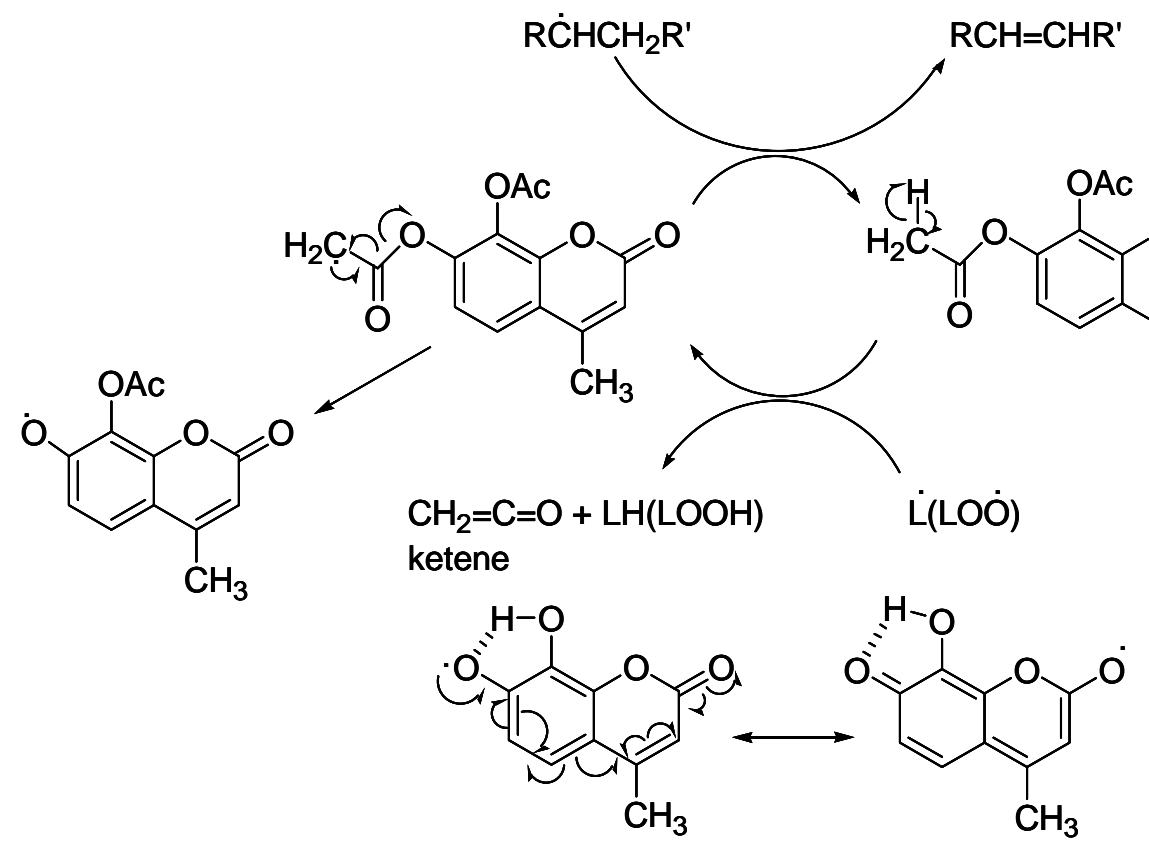

Reduced fom of lipids: $\mathrm{LH} / \mathrm{LOOH}$ Oxidised form of lipids: L'/ LOO radicals

Scheme 1. Proposed reaction of DAMC and DHMC showing radical structures.

These properties of the coumarin derivatives highlight them as superior antioxidants. Investigations on several types of flavonoids allowed to conclude that the catechol moiety 
We have also used the $\mathrm{pH}$ measurement techniques to study the mechanistic action of DAMC and DHMC to inhibit lipid peroxidation. These studies confirm the formation of a stable ADPFe-inhibitor (e.g. ADP-Fe-DHMC) mixed ligand complex, thereby inhibiting the ROS which is responsible for lipid peroxidation. ${ }^{19}$

Table 1. Radical scavenging potential of diacetoxy- and dihydroxy-4-methylcoumarins

\begin{tabular}{|c|c|}
\hline Compound & Scavenging of DPPH $\mathrm{IC}_{50}(\mu \mathrm{M})$ \\
\hline 7,8-Dihydroxy-4-methylcoumarin (2) & 14 \\
\hline 7,8-Diacetoxy-4-methylcoumarin (3) & 31 \\
\hline $\begin{array}{c}\text { 7,8-Diacetoxy-3-ethoxycarbonylethyl-4- } \\
\text { methylcoumarin (4) }\end{array}$ & 85 \\
\hline 6,7-Diacetoxy-4-methylcoumarin (5) & 31 \\
\hline $\begin{array}{c}\text { 6,7-Diacetoxy-3-ethoxycarbonylethyl-4- } \\
\text { methylcoumarin (6) }\end{array}$ & 172 \\
\hline Ascorbic acid (7) & 35 \\
\hline
\end{tabular}

DPPH: Diphenylpicrylhydrazyl reagent

Although polyphenolic compounds containing "free" hydroxyl groups (-OH) are known to be antioxidants, the antioxidant action of the acetoxy (-OAc) compound DAMC was intriguing (Table 2). Hence, pulse radiolysis studies were undertaken to explain the antioxidant action of DAMC. Accordingly, DAMC and DHMC were separately reacted with the system generating azide radicals and the resulting transient UV spectra were recorded. ${ }^{20}$

Table 2. Scavenging of superoxide radical by DHMC and DAMC

\begin{tabular}{ccc}
\hline & $\begin{array}{c}\text { Cytochrome C reduced } \\
(\mu \mathrm{mol} / \mathrm{min} .)\end{array}$ & $\begin{array}{c}\text { Superoxide scavenging } \\
(\text { no. of folds })\end{array}$ \\
\hline Control & 2730 & 0 \\
DHMC & 633 & 4.31 \\
DAMC & 793 & 3.44 \\
\hline
\end{tabular}

${ }^{a}$ Superoxide radical generated during the reaction catalysed by xanthine oxidase is utilized for the scavenging action of the test compounds. The values expressed are mean of three experiments with variation $<5 \%$.

The spectra of transient species obtained from DHMC and DAMC, produced on their reaction with azide radicals were studied thoroughly. We proposed that the mechanism of scavenging of reactive oxygen species (ROS) by DAMC and DHMC is quite similar. The results tabulated in Table 2 confirm the notion that both of these compounds 2 and $\mathbf{3}$ were found to scavenge superoxide radicals very efficiently. These results suggest that the free radical mediated 
oxidation of DAMC and DHMC initially produce a radical cation that may lose an acetyl carbocation to produce phenoxy radical (Scheme 2).<smiles>Cc1cc(=O)oc2c(O)c(O)ccc12</smiles><smiles>Cc1cc(=O)oc2c(O)c(O)ccc12</smiles>

DHMC- phenoxyl radical<smiles>CC(=O)Oc1ccc2c(C)cc(=O)oc2c1OC(C)=O</smiles>

DAMC

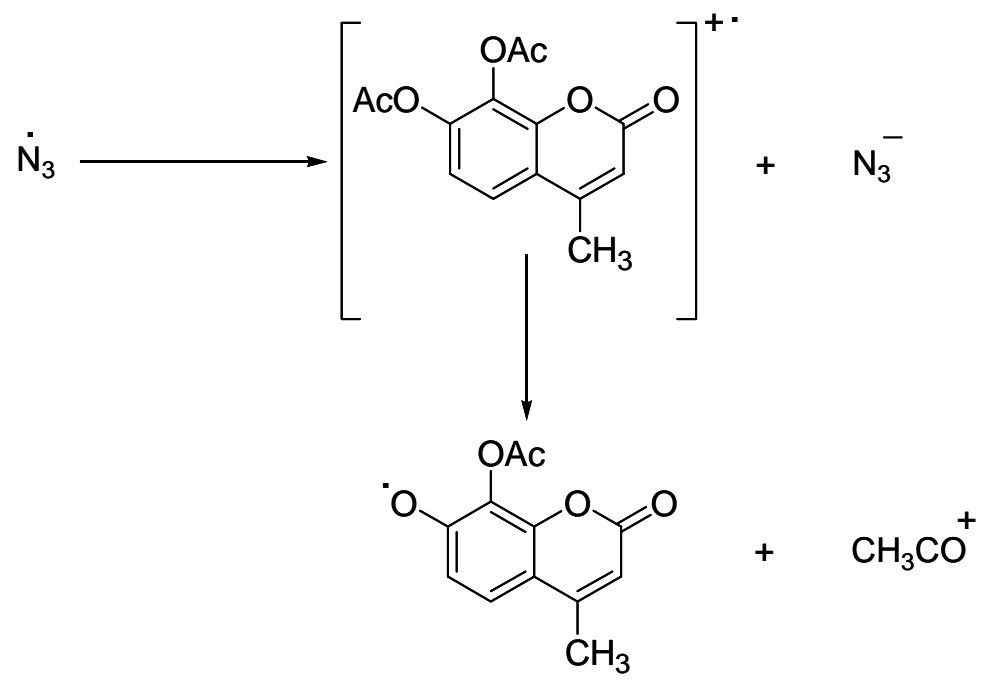

DAMC- phenoxyl radical

Scheme 2. Comparison of azide free radical interactions with DHMC and DAMC.

The root cause of inflammation is the increased expression of cell adhesion molecules (CAM) on the surface of endothelial cells which leads to indiscriminate infiltration of the leukocytes across the blood vessels causing inflammatory diseases. This increase is induced by various inflammatory mediators like TNF- $\alpha$, IL- $\beta$, bacterial lipopolysaccharides, etc. In the recent past, some antioxidants have shown to downregulate the expression of intercellular cell adhesion molecule-1 (ICAM-1) on endothelial cells. ${ }^{21}$ In order to understand the mechanisms underlying the anti-inflammatory activities and for establishing structure-activity relationships, 
we have synthesized different derivatives of oxygenated and thiono-4-methylcoumarins and have studied their effects on TNF- $\alpha$ induced expression of ICAM-1 on endothelial cells and on NADPH-catalyzed rat liver microsomal lipid peroxidation. Our data showed that dihydroxy and diacetoxy derivatives of thionocoumarins were more potent in comparison to the corresponding coumarin derivatives in inhibiting TNF- $\alpha$ induced expression of ICAM-1. However, coumarin derivatives were more potent in comparison to the corresponding thionocoumarins in inhibiting microsomal lipid peroxidation. We have also tested the intermediate compounds 7,8dibenzyloxy-4-methylcoumarin and 7,8-dibenzyloxy-4-methylthionocoumarin for their inhibitory activity on TNF- $\alpha$ induced ICAM-1 expression. Our study indicated that dibenzyloxy4-methylthionocoumarin is better than dibenzyloxy-4-methylcoumarin. The mechanisms underlying the observed activities of coumarins and thionocoumarins have been investigated with reference to their structures, such structure-activity relationship studies may help in developing molecules with better anti-inflammatory and anti-oxidant activities. ${ }^{22}$

We have further extended our studies and synthesized a new series of 4-methylcoumarin derivatives bearing different functionalities viz., halo, unsaturated hydrocarbon chains, etc. They have been screened for evaluation of the antioxidant activities by $\beta$-carotene-linoleate model system. Theoretical values of Bond Dissociation Enthalpy (BDE) of these coumarins were compared with the antioxidant activity values calculated by $\beta$-carotene-linoleate model system. ${ }^{23}$ According to this model system, the percent antioxidant activity decrease from dihydroxy to monohydroxy coumarins is consistent with the trend for BDE values and the antioxidant activities are comparable with BDE values (unpublished results from our Laboratories).

We have reported the existence of a novel microsomal deacetylase in rat liver catalyzing deacetylation of diacetoxy 4-methylcoumarins. A simple method was outlined for the enzyme assay based upon the quantification of the dihydroxy derivative by measuring the UV absorption of its complex with ADP and $\mathrm{Fe}^{3+}$ ions at $600 \mathrm{~nm}$. The enzyme was routinely assayed using 7,8diacetoxy-4-methylcoumarin (DAMC) as the substrate and demonstrated hyperbolic kinetics and yielded $\mathrm{Km}$ and $\mathrm{V}_{\max }$ values of $1250 \mu \mathrm{M}$ and 500 units, respectively. The $\mathrm{pH}$ optimum was found to be 7.5 for the enzyme. No DAMC deacetylase activity was found in hepatic cytosol and the enzyme activity was not discernible in extra hepatic tissues. ${ }^{24}$

We have discovered a membrane-bound enzyme catalyzing the transfer of acetyl groups from the acetyl donor 7,8-diacetoxy-4-methylcoumarin (DAMC) to glutathione S-transferase 3-3 (GST3-3), termed Acetoxy Drug (DAMC):protein transacetylase (TAase). The purified enzyme was incubated with recombinant GST 3-3 subunit and DAMC, the modified protein was isolated by sodium dodecyl sulfate-polyacrylamide gel electrophoresis (SDS-PAGE) in gel digested with trypsin and the tryptic digest was analyzed by mass spectrometry. The N-terminus and six lysines, Lys-51, -82, -124, -181, -191 and -210 , were found to be acetylated. The acetylation of GST 3-3 described above was not observed in the absence of either DAMC or TAase. These results clearly establish the phenomenon of protein acetylation independent of acetyl CoA catalyzed by a hitherto unknown enzyme (TAase) utilizing a certain xenobiotic acetate (DAMC) as the active acetyl donor. ${ }^{25}$ 
The investigations on the specificity for transacetylase (TAase) with respect to the number and positions of acetoxy groups on the benzenoid ring of coumarin molecule revealed that acetoxy groups in proximity to the oxygen heteroatom (at C-7 and C-8 positions) demonstrate a high degree of specificity to TAase. ${ }^{26}$

The cardinal role of the pyran ring carbonyl group in the acetoxy polyphenolic compounds for the acetoxy drug: protein transacetylase (TAase) activity was also proposed by us. Hence, an attempt was made to examine the effectiveness of substrate analogues of polyphenolic peracetate lacking pyran ring carbonyl group, such as 7-acetoxy-3,4-dihydro-2,2dimethylbenzopyran, catechin pentaacetate and hematoxylin pentaacetate as the substrates to TAase. No TAase activity appeared when these compounds were used as the substrates for TAase, thereby confirming the absolute requirement of the pyran carbonyl group for the catalytic activity of TAase. $^{26}$

We have also demonstrated that the acetoxy phenylcoumarins (having a phenyl ring instead of a methyl group at the C-4 position) and acetoxy dihydrocoumarins, when used as the substrates, yielded TAase activity, while the saturation of double bond at C-3 and C-4 position had no effect on the TAase activity. ${ }^{27}$ A comparison of the optimized structures of 7,8diacetoxy-4-methylcoumarin and 7,8-diacetoxy-4-phenylcoumarin suggested that the observed influence may be due to the out of plane configuration of the phenyl ring at C-4. ${ }^{27}$

DAMC and other acetoxycoumarins, with no prerequisite for oxidative biotransformation have been reported to produce suicide inactivation of microsomal cytochrome P450-catalyzed formation of aflatoxin $\mathrm{B}_{1}-8,9$-epoxide that binds to DNA. Parenteral administration of DAMC and other acetoxycoumarins to rats caused significant inhibition of $\mathrm{AFB}_{1}$ binding to DNA in vivo as well as $\mathrm{AFB}_{1}$-induced micronuclei formation in bone marrow and lung cells. These results highlight the antimutagenic potential of acetoxycoumarins. ${ }^{28-30}$

We have also found that another protein, i.e. hepatic NADPH cytochrome C reductase (an enzyme participating in the microsomal electron transport in cytochrome P-450 cycle) was shown to be remarkably activated by DAMC and acetoxy polyphenols unlike the inhibitory action of former on P-450 catalyzed oxidation. The catalytic activity of the enzyme enhanced nearly $600 \%$ by $25 \mu \mathrm{M}$ of DAMC after $10 \mathrm{~min}$ of pre-incubation. DAMC also proved to be effective in significantly enhancing the activity of NADPH cytochrome $\mathrm{C}$ reductase in vivo. DHMC, the deacetylated product of DAMC failed to irreversibly activate the enzyme. The activation effect of DAMC upon the enzyme was abolished by $p$-hydroxymercury benzoate. The role of a transacetylase in transferring the acetyl group of DAMC to the amino acid(s) of the active site of NADPH cytochrome $\mathrm{C}$ reductase causing irreversible enzyme activation has been enunciated by us. $^{27,31}$

An enhanced intracellular level of nitric oxide (NO) is essential to ameliorate several pathological conditions of heart and vasculature necessitating the activation of NOS. The enzymology of nitric oxide synthase (NOS) has revealed that NOS is a multidomain enzyme complex. There are four cofactors, namely 5,6,7,8-tetrahydrobiopterins (BH4), heme, FMN and FAD distributed over the oxygenase and reductase domains of NOS. The reductase domain 
appears to be rate limiting in the formation of NO from arginine. We have reported the acetylation of the enzyme, endothelium nitric oxide synthase (eNOS) by polyphenolic peracetates (PA) catalyzed by the novel enzyme TAase discovered in our laboratory as an unambiguous way of activating NOS which results in the manifestation of its physiological actions. The human platelet was chosen as the experimental system in order to validate the aforementioned proposition. PA caused profound irreversible activation of platelet NADPH cytochrome c reductase mediated by TAase. The convincing biochemical evidences were presented to show that PA could cause acetylation of the reductase domain of NOS leading to the activation of eNOS in tune with their specificities to platelet TAase. As a result, the enhanced levels of NO due to activation of platelet eNOS by PA were found to inhibit the ADP-induced platelet aggregation. The studies highlighted for the first time the role of PA as the novel potent agent for enhancing the intracellular NO levels. ${ }^{32}$ The activation of NADPH cytochrome c reductase and intracellular NO levels and cytochrome P-450 linked MFO by acetoxy polyphenols were established as the TAase related biological effects.

We have purified the TAase from rat liver microsomes to homogeneity and it exhibited the mol. wt. of $55 \mathrm{KDa}$. The N-terminal sequence showed $100 \%$ homology with N-terminal sequence of mature calreticulin (CRT). The identity of TAase with CRT, an endoplasmic reticulum (ER) protein, was evidenced by the demonstration of the properties of CRT such as immunoreactivity with anti-calreticulin, binding to $\mathrm{Ca}^{2+}$ ions and being substrate for phosphorylation by protein kinase $\mathrm{C}(\mathrm{PKC})$, which are the hallmark characteristics of CRT. TAase-catalyzed protein acetylation by PAs was evidenced by the demonstration of immunoreactivity of the acetylated target protein, such as cytochrome P-450 reductase and nitric oxide synthase (NOS) with anti-acetyl lysine. The possible acetylation of human platelet NOS by PA as described above resulted in the enhancement of intracellular levels of nitric oxide (NO). PAs, unlike the parent polyphenols, exhibited NO-related physiological effects, such as inhibition of ADP-induced platelets aggregation. These observations, for the first time convincingly attribute the transacetylase function to CRT, which possibly plays an important role in protein modification by way of carrying auto acetylation of certain functional proteins through a biochemical mechanism independent of acetyl CoA. ${ }^{33}$

\section{Xanthones}

Reactive oxygen species are primary signaling molecules in regulating the expression of intercellular adhesion molecule-1 (ICAM-1) on endothelial cells and hence play an important role in various inflammatory diseases. ${ }^{34,35}$ Xanthones are the compounds that inhibit lipid peroxidation and influence the generation of ROS that in turn lead to the decreased expression of cell adhesion molecules and subsequently decreased inflammation. ${ }^{35,36}$ The observance of these facts invoked us to understand the mechanisms underlying the anti-inflammatory activities of xanthones and for studying their structure-activity relationship. We have synthesized various 
hydroxy, acetoxy and methoxyxanthones 8-16 (Figure 2) and studied their effect on the initiation of lipid peroxidation in liver microsomes to examine their antioxidant property (Table 3 ). ${ }^{37}$<smiles>O=c1c2ccccc2oc2cccc(O)c12</smiles>

8<smiles>O=c1c2ccc(O)cc2oc2ccc(O)cc12</smiles>

11<smiles>O=c1c2ccccc2oc2cc(O)ccc12</smiles>

9<smiles>O=c1c2ccccc2oc2c(O)ccc(O)c12</smiles>

10<smiles>CC(=O)Oc1ccc2c(=O)c3cc(OC(C)=O)ccc3oc2c1</smiles>

12

13<smiles>COc1ccc2c(=O)c3ccccc3oc2c1</smiles>

14<smiles>COc1cc(OC)c2c(=O)c3cc(OC)ccc3oc2c1</smiles>

15<smiles>COc1ccc2c(=O)c3c(O)cccc3oc2c1O</smiles>

16

Figure 2. Structures of xanthones screened.

Table 3. Effect of xanthones on NADPH-dependent inhibition of lipid peroxidation initiation

\begin{tabular}{ccc}
$\begin{array}{c}\text { Compound } \\
\text { No. }\end{array}$ & Compound name & $\begin{array}{c}\text { NADPH-dependent lipid } \\
\text { peroxidation initiation, } \\
\text { percent of the control }\end{array}$ \\
\hline $\mathbf{8}$ & 1-Hydroxyxanthone & 28 \\
$\mathbf{9}$ & 3-Hydroxyxanthone & 38 \\
$\mathbf{1 0}$ & 1,4-Dihydroxyxanthone & 60 \\
$\mathbf{1 1}$ & 2,6-Dihydroxyxanthone & 43 \\
$\mathbf{1 2}$ & 1,2-Diacetoxyxanthone & 30 \\
$\mathbf{1 3}$ & 2,6-Diacetoxyxanthone & - \\
$\mathbf{1 4}$ & 3-Methoxyxanthone & 2 \\
$\mathbf{1 5}$ & 1,3,7-Trimethoxyxanthone & 0 \\
$\mathbf{1 6}$ & 1,5-Dihydroxy-6-methoxyxanthone & - \\
\hline
\end{tabular}

The hydroxylated xanthones showed high to moderate activity (Table 3). On the other hand, the dihydroxyxanthones show increased activity as compared to monohydroxy xanthones. The methoxylated xanthones 14, 15 and 16 did not show any appreciable inhibition of initiation of 
lipid peroxidation. Further, the inhibition of initiation of lipid peroxidation by 1,2diacetoxyxanthone is comparable with 1-hydroxyxanthone $8{ }^{37}$ The ICAM-1 inhibitory activity of diacetoxy xanthones $\mathbf{1 2}$ and $\mathbf{1 3}$ may be because of in-situ enzymatic deacetylation of these compounds leading to the formation of the corresponding dihydroxyxanthone $\mathbf{1 1}$ and XII (Scheme 3). These in turn may be oxidized to the corresponding quinonoid xanthones XI and XIII, the species that may really be responsible for the observed activities. The stability of the ortho quinonoid xanthone XIII is less than the stability of the para-quinonoid xanthone $\mathbf{X}$. Therefore, compound $\mathbf{1 0}$ exhibited maximum activity. However, the quinonoid form XIII derived from 12 is more stable than the charge separated quinonoid form XI derived from the diacetoxy xanthone 11. Surprisingly, the xanthone 16, in spite of having two hydroxy groups does not exhibit any noticeable activity, which may be because of the fact that this compound cannot oxidize, as no quinonoid structure form can be generated.
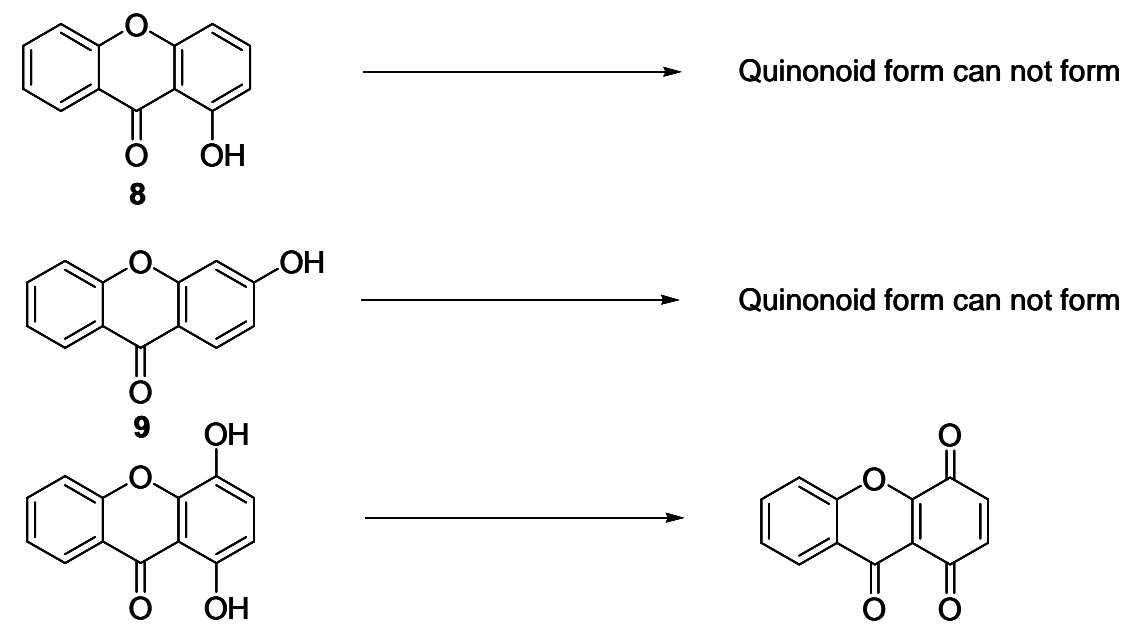

10

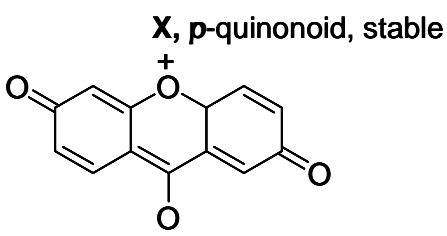

$\mathbf{X I}, \mathbf{p}$-quinonoid with positive charge on oxygen,

11 unstable
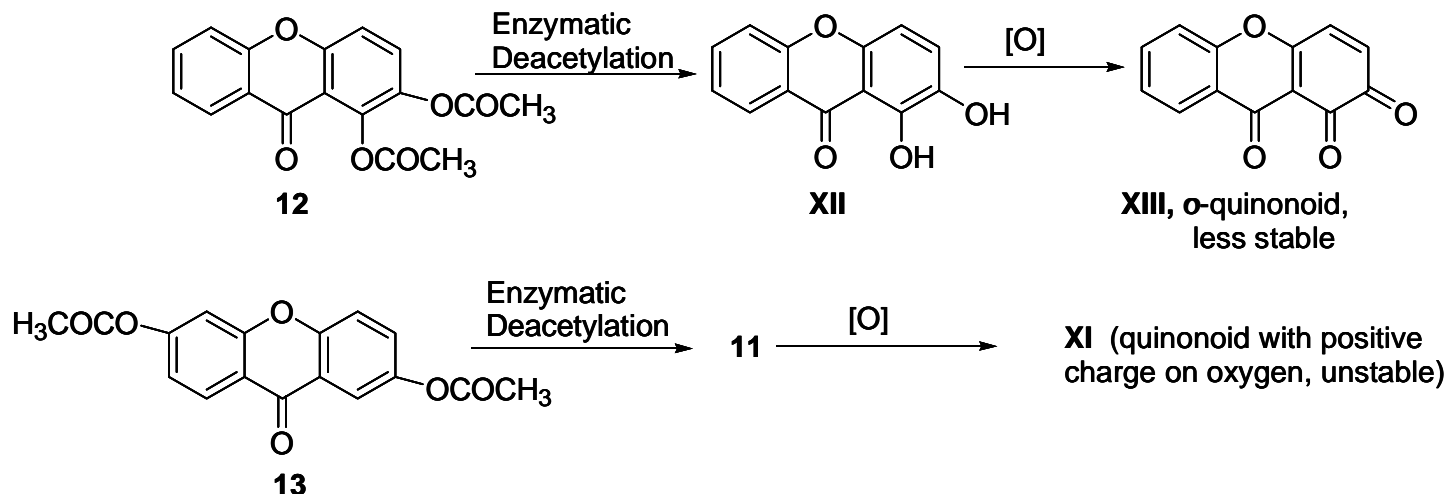

Scheme 3. Proposed mechanism of conversion of xanthones to their respective quinonoid forms. 
We have demonstrated that 1,4-dihydroxyxanthone (1,4-DHX) inhibits the expression of cell adhesion molecules, such as ICAM-1, VCAM-1 and E-selectin, on endothelial cells in a concentration and time dependent manner. The inhibition by 1,4-DHX is reversible. On further analysis, it appears that 1,4-DHX inhibits the adhesion of peripheral neutrophils to the endothelial cell monolayers. 1,4 DHX, therefore, could be used as a novel target for controlling various pathological conditions associated with upregulation of endothelial leukocyte adhesion molecules. $^{38}$

\section{Pyrazoles and Acrylonitriles}

In addition to coumarins and xanthones, we have studied the antioxidant activity of a new class of heterocyclic compounds, i.e. pyranones (lactones) 17, 5-arylpyrazoles 18, 1,3-diarylpyrazoles 21, and acrylonitriles 19, 20 and 22 (Figure 3). Pyrazoles and their derivatives are widely used as medicines, e.g. antipyretic, ${ }^{39}$ anti-inflammatory, ${ }^{40}$ gastric secretion stimulatory, ${ }^{41}$ antidepressant, ${ }^{42}$ against rheumatoid arthritis and antihypercholesterolemic agents, ${ }^{43}$ antibacterial agents, ${ }^{44}$ etc. This class of compounds are also useful as agrochemicals, e.g. as pesticides, ${ }^{45}$ insecticides, in sunscreen materials, and as analytical reagents. Owing to these widespread applications, we have synthesized and evaluated the biological activities of pyrazoles and their derivatives. $^{46}$

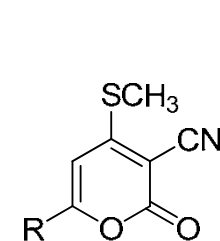

17

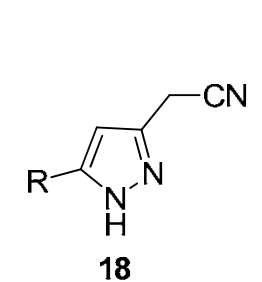<smiles>[R]c1cc(/C(C#N)=C/c2ccc[nH]2)n[nH]1</smiles><smiles>[R]c1cc(/C(C#N)=C\c2ccc[nH]2)n[nH]1</smiles>

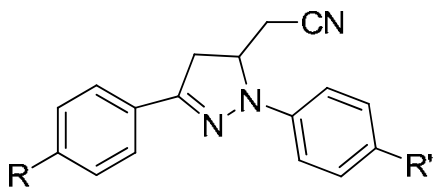

21

\begin{tabular}{c|l} 
17-20 & \multicolumn{1}{|c}{$\mathbf{R}$} \\
\hline a & $\mathrm{Ph}-$ \\
b & $4-\mathrm{CH}_{3}-\mathrm{C}_{6} \mathrm{H}_{4^{-}}$ \\
c & $4-\mathrm{F}_{-} \mathrm{C}_{6} \mathrm{H}_{4^{-}}$ \\
d & $3-\mathrm{CH}_{3} \mathrm{O}_{-} \mathrm{C}_{6} \mathrm{H}_{4^{-}}$ \\
e & $3-\mathrm{Br}_{6} \mathrm{C}_{6} \mathrm{H}_{4-}$ \\
f & $4-\mathrm{CH}_{3} \mathrm{O}^{-} \mathrm{C}_{6} \mathrm{H}_{4-}$ \\
g & $4-\mathrm{Cl}-\mathrm{C}_{6} \mathrm{H}_{4^{-}}$ \\
h & $4-\mathrm{Br}-\mathrm{C}_{6} \mathrm{H}_{4^{-}}$
\end{tabular}<smiles>[R]c1ccc(-c2cc(/C(C#N)=C/c3ccc[nH]3)n(-c3ccc([R])cc3)n2)cc1</smiles>

22

\begin{tabular}{c|ll}
$\mathbf{2 1 - 2 2}$ & $\mathbf{R}$ & $\mathbf{R}$ \\
\hline a & $\mathrm{H}$ & $\mathrm{H}$ \\
b & $\mathrm{Me}$ & $\mathrm{H}$ \\
c & $\mathrm{Cl}$ & $\mathrm{H}$ \\
d & $\mathrm{Br}$ & $\mathrm{F}$ \\
& &
\end{tabular}

Figure 3. Structures of compounds screened. 
Table 4. Inhibitory effect of pyranones and cyanomethylpyrazoles on lipid peroxidation in rat liver microsomes initiated by NADPH

$\begin{array}{lccc}\text { Compound } & \text { \% Inhibition of initiation } & \text { Compound } & \text { \% Inhibition of initiation } \\ \text { 17a } & 3 & \text { 18d } & 27 \\ \text { 17b } & 14 & \mathbf{1 8 e} & 33 \\ \mathbf{1 7 d} & 4 & \mathbf{1 8 f} & 10 \\ \mathbf{1 7 g} & 14 & \mathbf{1 8 h} & 18 \\ \mathbf{1 7 h} & 18 & \mathbf{2 1 a} & 33 \\ \mathbf{1 8 a} & 33 & \mathbf{2 1 b} & 33 \\ \mathbf{1 8 b} & 31 & \text { 21c } & 26 \\ \text { 18c } & 35 & & \end{array}$

Table 5. Inhibitory effect of 2-pyrazolyl-3-(pyrrol-2-yl)acrylonitriles on lipid peroxidation in rat liver microsomes initiated by NADPH

Compound $\quad \%$ Inhibition of initiation Compound $\quad \%$ Inhibition of initiation

$\begin{array}{llll}\text { 19a } & 53 & \text { 19f } & 42 \\ \text { 20a } & 73 & \text { 20f } & 68 \\ \text { 19b } & 69 & \mathbf{1 9 g} & 27 \\ \text { 20b } & \mathbf{2 0 g} & 90 \\ \text { 19c } & 95 & \mathbf{1 9 h} & 77 \\ \text { 20c } & 52 & \mathbf{2 0 h} & 68 \\ \text { 19d } & 67 & \mathbf{2 2 a} & 36 \\ \text { 20d } & 20 & \mathbf{2 2 b} & 48 \\ \text { 19e } & 62 & \text { 22c } & 87 \\ \text { 20e } & 42 & \text { 22d } & 80\end{array}$

We have investigated the effect of above pyranone and pyrazole derivatives at both initiation and propagation steps. Pyrazolylacrylonitriles have neither radical scavenging ability, nor they can inhibit Mixed Function Oxidase, MFO (data not shown). But, there exists the possibility of pyrazolylacrylonitriles forming a stable complex with ADP-perferryl radical responsible for ROS formation as we have shown earlier in the case of dioxygenated 4-methylcoumarins. ${ }^{19} \mathrm{NADPH}-$ dependent liver microsomal lipid peroxidation was assayed by the method of Ernster and Nordenbrand. ${ }^{47}$ The results illustrated that pyranones do not exhibit significant activity to inhibit the initiation of NADPH-catalyzed peroxidation of lipids of rat liver microsomes. Whereas, conversion of pyranones to arylpyrazoles and to 1,3-diarylpyrazoles increases the activity by 0 to 11 fold in different cases (Tables $4 \& 5$ ). The maximum increase in activity has been observed in 
pyrazoles with unsubstituted phenyl ring/rings derived from the corresponding pyranones. In addition, methyl- or methoxyphenylpyrazolylacrylonitriles are found to have better antioxidant activity than unsubstituted, or fluoro- or chlorosubstituted phenylpyrazolylacrylonitriles.

\section{Flavones and Isoflavones}

Stray ROS not only initiate lipid peroxidation in healthy cells but even the induction of human cancer involves a multistep process, initiated with DNA damage by endogenous reactive oxygen species (ROS) and exogenous activated carcinogens, followed by oncogene activation and tumor suppressor gene mutations, and finally lead to the alteration of different signaling pathways. Flavonoids are widely distributed in plants fulfilling many functions including producing yellow or red/blue pigmentation in flowers and protection from attack by microbes and insects. Flavonoids have been referred to as "nature's biological response modifiers" because of strong experimental evidence of their inherent ability to modify the body's reaction to allergens, viruses, and carcinogens. They show anti-allergic, anti-inflammatory, anti-microbial and anti-cancer activities. In addition, flavonoids act as powerful antioxidants, protecting against oxidative and free radical damage.

We have isolated various flavones and isoflavones from natural sources, and also synthesized large number of these types of compounds by chemical methods. These compounds were subjected for anti-invasive activity evaluation.

Invasion is the hallmark of malignant tumors, and is responsible for the bad prognosis of the untreated cancer patients. The search for anti-invasive treatments led us to screen compounds of different classes for their effect in an assay for invasion. Invasion of MCF-7/6 human mammary carcinoma cells into embryonic chick heart fragments was studied in organ culture during 8 days. The effect of various polyphenolic compounds, belonging to the classes of flavonoids, chalcones, coumarins, desoxybenzoins, aromatic ketones, etc. were tested in this assay for invasion.

Two flavones with very similar physical behavior and spectral profile have been isolated as minor constituents from the seeds of Tephrosia candida. The structures of these compounds have been established on the basis of a detailed and critical study of their mass spectra, extent of shifts in their UV spectra, X-ray diffraction studies, and prepration of their derivatives. One of these was the known compound, penduletin (23), while the other was a new natural compound, viz. 5-hydroxy-2-(4-hydroxyphenyl)-3,6,8-trimethoxy-4H-1-benzopyran-4-one (24), for which the name candirone was proposed (Figure 4$).{ }^{48}$ 
<smiles>COc1cc2oc(-c3ccc(O)cc3)c(OC)c(=O)c2c(O)c1OC</smiles>

23<smiles>COc1cc(OC)c2oc(-c3ccc(O)cc3)c(OC)c(=O)c2c1O</smiles>

24

Figure 4. Structures of compounds isolated from Tephrosia candida.

Seven compounds were isolated from the heartwood of Prunus domestica. Two of them, 5,7,4'-trihydroxy-3-methoxyflavanone (25) and 3,5,7-trihydroxy-6,4'-dimethoxyflavan-one (26), were new natural products (Figure 5). ${ }^{49}$

Three new compounds, namely 5,7-dihydroxy-6,8-dimethoxy-2-(3,5-dihydroxy-4methoxyphenyl)-4H-1-benzopyran-4-one (27), 5,7-dihydroxy-6-methoxy-2-(3,5-dihydroxy-4methoxyphenyl)-4H-1-benzopyran-4-one (28) and 5,7-dihydroxy-6-methoxy-2-(2,4dihydroxyphenyl)-4H-1-benzopyran-4-one (29), were isolated as an inseparable mixture from the aerial parts of Tamarix dioica (Figure 6). ${ }^{50}$ Two new flavones, 5,7,2'-trihydroxy-6,4'dimethoxyflavone (tamaridone, 30) and 5,2',4'-trihydroxy-6,7,8-trimethoxyflavone (tamadone, 31) were also isolated from the aerial parts of Tamarix dioica, along with hexacosyl-pcoumarate, gardenins A, B, C and E, nevadensin A and apigenin (Figure 6). ${ }^{51}$ Gardenin B (32) exhibited antiviral activity and anti-invasive activity against solid tumors (Figure 6).<smiles>COC1C(=O)c2c(O)cc(O)cc2OC1c1ccc(O)cc1</smiles>

25<smiles>COc1ccc(C2Oc3cc(O)c(OC)c(O)c3C(=O)C2O)cc1</smiles>

26

Figure 5. Structures of compounds isolated from Prunus domestica. 
<smiles>COc1c(O)cc(-c2cc(=O)c3c(O)c(OC)c(O)c(OC)c3o2)cc1O</smiles>

27<smiles>COc1c(O)cc2oc(-c3ccc(O)cc3O)cc(=O)c2c1O</smiles>

29<smiles>COc1c(OC)c(O)c2c(=O)cc(-c3ccc(O)cc3O)oc2c1OC</smiles>

31<smiles>COc1c(O)cc(-c2cc(=O)c3c(O)c(OC)c(O)cc3o2)cc1O</smiles>

28<smiles>COc1ccc(-c2cc(=O)c3c(O)c(OC)c(O)cc3o2)c(O)c1</smiles><smiles>COc1ccc(-c2cc(=O)c3c(O)c(OC)c(OC)c(OC)c3o2)cc1</smiles>

Figure 6. Structures of compounds isolated from Tamarix dioica

Tangeretin (33) is a methoxyflavone from citrus fruits, which inhibits growth of human mammary cancer cells and cytolysis by natural killer cells (Figure 7). Attempting to unravel the flavonoid's action mechanism, we found that it inhibited extracellular-signal-regulated kinases $1 / 2$ (ERK1/2) phosphorylation in a dose- and time-dependent manner. In human T47D mammary cancer cells, this inhibition was optimally observed after priming with estradiol. The spectrum of the intracellular signalling kinase inhibition was narrow and comparison of structural congeners showed that inhibition of ERK phosphorylation was not unique for tangeretin. Our data add tangeretin to the list of small kinase inhibitors with a restricted intracellular inhibition profile. ${ }^{52}$ The anti-invasive activity of 3,7-dimethoxyflavone (34) was found at concentrations ranging from 1 to $100 \mu \mathrm{M}$ (Figure 7). At these anti-invasive concentrations, no cytotoxic effects were detected: the anti-invasive effect was reversible upon omission of the molecule from the medium. ${ }^{53,54}$ 


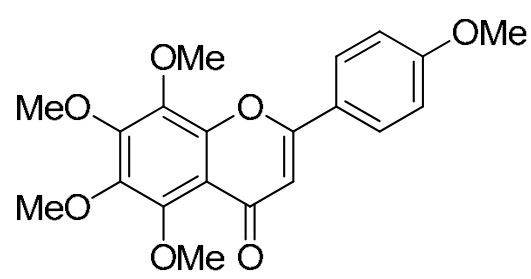

33<smiles>COc1ccc2c(=O)c(OC)c(-c3ccccc3)oc2c1</smiles>

34

Figure 7. Structures of compounds isolated from citrus fruits.

Our data indicates that some polyphenolic and heterocyclic compounds are anti-invasive without being cytotoxic for the cancer cells. ${ }^{55}$

\section{Conclusions}

In conclusion, naturally occurring coumarins, such as 8-acetyl-7-hydroxy-6-methoxycoumarin, 8-methoxycoumarin, trigoforin, troupin and trigocoumarin (reported several years ago as new natural products by us) and a wide variety of their synthetic analogues have been subjected to screening for inhibition of NADPH-catalysed peroxidation of rat liver microsomes which led to the identification of potent anti-oxidant compounds. This study may be of significance for the development of clinical antioxidant agents. Our study indicates the existence of a novel microsomal deacetylase in rat liver catalyzing deacetylation of diacetoxy-4-methylcoumarins. The role of a transacetylase in transferring the acetyl group of DAMC 3 and other acetoxycoumarins to certain functional proteins, such as NADPH cytochrome $\mathrm{C}$ reductase and nitric oxide synthase causing irreversible activation of the reductase and intracellular levels of nitric oxide are enunciated. 1,4-Dihydroxyxanthone (10) showed good antioxidant activity as well as inhibition of the expression of cell adhesion molecules, such as ICAM-1, VCAM-1 and E-selectin, on endothelial cells. Methyl- or methoxyphenylpyrazolylacrylonitriles showed better antioxidant activity than unsubstituted, or fluoro- or chlorosubstituted phenylpyrazolylacrylonitriles. Also quite a few naturally occurring flavones and their synthetic analogues exhibited antiviral activity and anti-invasive activity against solid tumors.

\section{Acknowledgements}

This work was supported by a grant from the Department of Scientific and Industrial Research (DSIR, DST, Govt. of India, New Delhi) and the Italian Ministry for University and Research, General Management for Strategies and Development of Internationalization of Scientific and Technological Research. 


\section{References}

1. Buege, J. A.; Aust, S. D. Methods Enzymol. 1978, 30, 302.

2. Duthie, G. G. Eur. J. Clin. Nutr. 1993, 47, 759.

3. Cutler, R. G. Free Radicals in Biology; Pryor, W. A., Ed.; Academic Press: London, 1984; Vol. 6; Chapter 11.

4. Melhorn, R. J.; Cole G. In Advances in Free Radical Biology and Medicine; Pergamon Press: Oxford, 1985; Vol. 1, p 165.

5. Sohal, R. S.; Allen, R. G. Advances in Free Radical Biology and Medicine; Pergamon Press: Oxford, 1986; Vol. 2, p 117.

6. Takeda, S.; Aburada, M. J. Pharmacobiodyn. 1981, 4, 724.

7. Deana, A. A.; Stokker, G. E.; Schultz, E. M.; Smith, R. L.; Cragoe, E. J.; Russo, H. F.; Watson, L. S. J. Med. Chem. 1983, 26, 580.

8. $\quad$ Nagarajan, G.; Rani, U. ; Parmar, V. S. Phytochemistry 1980, 19, 2494.

9. Khurana, S. K.; Krishnamoorthy, V.; Parmar, V. S.; Sanduja, R.; Chawla, H. L. Phytochemistry 1982, 21, 2145.

10. Parmar, V. S.; Rathore, J. S.; Singh, S.; Jain, A. K.; Gupta, S. R. Phytochemistry 1985, 24, 871.

11. Parmar, V. S.; Jha , H. N.; Sanduja, S. K.; Sanduja, R. Z. Naturforsch 1981, 37B, 521.

12. Sauvaire, Y.; Petit, P.; Broca, C.; Manteghetti, M.; Baissac, Y.; Alvarez, J. F.; Gross, R.; Roye, M.; Leconte, A.; Gomis, R.; Ribes, G. Diabetes 1998, 47, 206.

13. Lake, B. G. Food Chem. Toxicol. 1999, 37, 423.

14. Raj, H. G.; Gupta, S.; Prasad, A. K.; Boll, P. M.; Wengel, J.; Biswas, G.; Singh, S. K.; Sharma, N. K.; Bisht, K. S.; Parmar, V. S. Bioorg. Med. Chem. Lett. 1995, 5, 1567.

15. Raj, H. G.; Gupta, S.; Biswas, G.; Singh, S.; Singh, A.; Jha, A.; Bisht, K. S.; Sharma, S. K.; Jain, S. C.; Parmar, V. S. Bioorg. Med. Chem. 1996, 4, 2225.

16. Raj, H. G.; Parmar, V. S.; Jain, S. C.; Goel, S.; Poonam.; Himanshu.; Malhotra, S.; Singh, A.; Olsen, C. E.; Wengel, J. Bioorg. Med. Chem. 1998, 6, 833.

17. Husain, S. R.; Cillard, J.; Cillard, P. Phytochemistry 1987, 26, 2489.

18. Jha, H. C., Recklinghausen, V.; Zelliken, F. Biochem. Pharmacol. 1985, 34, 1367.

19. Raj, H. G.; Sharma, R. K.; Garg, B. S.; Parmar, V. S.; Jain, S. C.; Goel, S.; Tyagi, Y. K.; Singh, A.; Olsen, C. E.; Wengel, J. Bioorg. Med. Chem. 1998, 6, 2205.

20. Raj, H. G.; Parmar, V. S.; Jain, S. C.; Priyadarsini, K. I.; Mittal, J. P.; Goel, S.; Das, S. K.; Sharma, S. K.; Olsen, C. E.; Wengel, J. Bioorg. Med. Chem. 1999, 7, 2091.

21. Walther, M.; Kaffenberger, W.; Van, B. D. Int. J. Radiat. Biol. 1999, 75, 1317.

22. Kumar, S.; Singh, B. K.; Kalra, N.; Kumar, V.; Kumar, A.; Prasad, A. K.; Raj, H. G.; Parmar, V. S.; Ghosh, B. Bioorg. Med. Chem. 2005, 13, 1605.

23. Jayaprakasha, G. K.; Singh, R. P.; Sakariah, K. K. Food Chem. 2001, 73, 285.

24. Raj, H. G.; Parmar, V. S.; Jain, S. C.; Goel, S.; Tyagi, Y. K.; Sharma, S. K.; Olsen, C. E.; Wengel, J. Bioorg. Med. Chem. 2000, 8, 233. 
25. Kohli, E.; Gaspari, M.; Raj, H. G.; Parmar, V. S.; Van der, G. J.; Gupta, G.; Kumari, R.; Prasad, A. K.; Goel, S.; Pal, G.; Tyagi, Y. K.; Jain, S. C.; Ahmad, N.; Watterson, A. C.; Olsen C. E. FEBS Lett. 2002, 530, 139.

26. Singh, I.; Kohli, E.; Raj, H. G.; Gyanda, K.; Jain, S. K.; Tyagi, Y. K.; Gupta, G.; Kumari, R.; Kumar, A.; Pal, G.; Prasad, A. K.; Rastogi, R. C.; Olsen, C. E.; Jain, S. C.; Parmar, V. S. Bioorg. Med. Chem. 2002, 10, 4103.

27. Kumar, A.; Singh, B. K.; Tyagi, R.; Jain, S. K.; Sharma, S. K.; Prasad, A. K.; Raj H. G.; Rastogi, R. C.; Watterson, A. C.; Parmar, V. S. Bioorg. Med. Chem. 2005, 13, 4300.

28. Raj, H. G.; Parmar, V. S.; Jain, S. C.; Goel, S.; Singh, A.; Gupta, K.; Rohil, V.; Tyagi, Y. K.; Jha, H. N.; Olsen, C. E.; Wengel, J. Bioorg. Med. Chem. 1998, 6, 1895.

29. Raj, H. G.; Kohli, E.; Rohil, V.; Dwarkanath, B. S.; Parmar, V. S.; Malik, S.; Adhikari, J. S.; Goel, S.; Gupta, K.; Bose, M.; Olsen C. E. Mutat. Res. 2001, 494, 31.

30. Kumar, A.; Tyagi, Y. K.; Seema.; Ponnan, P.; Rohil, V.; Prasad, A. K.; Dwarakanath, B. S.; Raj, H. G.; Parmar, V.S. J. Pharm. Pharmacol. 2007, 59, 81.

31. Raj, H. G.; Parmar, V. S.; Jain, S. C.; Goel, S.; Singh, A.; Tyagi, Y. K.; Jha, H. N.; Olsen, C. E.; Wengel, J. Bioorg. Med. Chem. 1999, 7, 369.

32. Khurana, P.; Kumari, R.; Vohra, P.; Kumar, A.; Seema.; Gupta, G.; Raj, H. G.; Dwarakanath, B. S.; Parmar, V. S.; Saluja, D.; Bose, M.; Vij, A.; Chaudhary, N. K.; Adhikari, J. S.; Tyagi, Y. K.; Kohli, E. Bioorg. Med. Chem. 2006, 14, 575.

33. Raj, H. G.; Kumari, R.; Seema.; Gupta, G.; Kumar, R.; Saluja, D.; Muralidhar, K. M.; Kumar, A.; Dwarkanath, B. S.; Rastogi, R. C.; Prasad, A. K.; Patkar, S. A.; Watterson, A. C.; Parmar, V. S. Pure Appl. Chem. 2006, 78, 985.

34. Cuzzocrea, S.; Mazzon, E.; Dugo, L.; Serranio, I.; Ciccolo, A.; Centorrino, T.; Sarro, A.; Caputi, A. P. FASEB J. 2001, 15, 1187.

35. Wang, J. P.; Raung, S. L.; Lin, C. N.; Teng, C. M. Eur. J. Pharmacol. 1994, 251, 35

36. Lin, C. N.; Chung, M. I.; Liou, S. J.; Lee, T. H.; Wang, J. P. J. Pharm. Pharmacol. 1996, 48, 532.

37. Madan, B.; Singh, I.; Kumar, A.; Prasad, A. K.; Raj, H. G.; Parmar, V. S.; Ghosh, B. Bioorg. Med. Chem. 2002, 10, 3431.

38. Madan, B.; Prasad, A. K.; Parmar, V. S.; Ghosh, B. Bioorg. Med. Chem. 2004, 12, 1431.

39. Wiley, R. H.; Wiley, P. Pyrazolones, Pyrazolidones and Derivatives; John Wiley and Sons: New York, 1964; p 102.

40. $\quad$ Rainer, G., Krueger, U., Klemm, K. Arzneim Forsch. 1981, 31, 649.

41. Rosiere, C. E.; Grossman, M. I. Science 1951, 113, 651.

42. Bailey, D. M.; Hansen, P. E.; Hlavac, A. G.; Baizman E. R.; Pearl, J.; Defelice, A. F.; Feigenson, M. E. J. Med. Chem. 1985, 28, 256.

43. Seki, K.; Watanabe, T. T.; Suga, T. Chem. Pharm. Bull. 1988, 36, 1117.

44. Mahajan, R. N.; Havaldar, F. H.; Fernandes, P. S. J. Indian Chem. Soc. 1991, 68, 245.

45. Londershausen, M. Pestic. Sci. 1996, 48, 269 
46. Parmar, V. S.; Kumar, A.; Prasad, A. K.; Singh, S. K.; Kumar, N.; Mukherjee, S.; Raj, H. G.; Goel, S.; Errington, W.; Puar, W. A. Bioorg. Med. Chem. 1999, 7, 1425.

47. Ernster, L.; Nordenbrand, K. Methods Enzymol. 1967, 10, 574.

48. $\quad$ Parmar, V. S.; Jain, R.; Simonsen, O.; Boll, P. M. Tetrahedron 1987, 43, 4241.

49. Parmar, V. S.; Vardhan, A.; Nagarajan, G. R.; Jain, R. Phytochemistry 1992, 31, 2185.

50. $\quad$ Parmar, V. S.; Taneja, P.; Singh, S.; Jain, R.; Sharma, S. K.; Boll, P. M.; Moller, J. Indian J. Chem. 1994, 33B, 305.

51. Parmar, V. S.; Bisht, K. S.; Sharma, S. K.; Jain, R.; Taneja, P.; Singh, S.; Simonsen, O.; Boll, P. M. Phytochemistry 1994, 36, 507.

52. Van Slambrouck, S.; Parmar, V. S.; Sharma, S. K.; De, B. B.; Fore, F.; Coopman, P.; Vanhoecke, B. W.; Boterberg, T.; Depypere, H. T.; Leclercq, G.; Bracke, M. E. FEBS Lett. 2005, 579, 1665.

53. Parmar, V. S.; Jain, R.; Sharma, S. K.; Vardhan, A.; Jha, A.; Taneja, P.; Singh, S.; Vyncke, B. M.; Bracke, M. E.; Mareel, M. M. J. Pharm. Sci. 1994, 83, 1217.

54. Parmar, V. S.; Bracke, M. E.; Philippe, J.; Wengel, J.; Jain, S. C.; Olsen, C. E.; Bisht, K. S.; Sharma, N. K.; Courtens, A.; Sharma, S. K.; Vennekens, K.; Van, M. V.; Singh, S. K.; Kumar, N.; Kumar, A.; Malhotra, S.; Kumar, R.; Rajwanshi, V. K.; Jain, R.; Mareel, M. M. Bioorg. Med. Chem. 1997, 5, 1609.

55. Parmar, V. S.; Sharma, N. K.; Husain, M.; Watterson, A. C.; Kumar, J.; Samuelson, L. A.; Cholli, A. L.; Prasad, A. K.; Kumar, A.; Malhotra, S.; Kumar, N.; Jha, A.; Singh, A.; Singh, I.; Himanshu.; Vats, A.; Shakil, N. A.; Trikha, S.; Mukherjee, S.; Sharma, S. K.; Singh, S. K.; Kumar, A.; Jha, H. N.; Olsen, C. E.; Stove, C. P.; Bracke, M. E.; Mareel, M. M. Bioorg. Med. Chem. 2003, 11, 913. 